\title{
EFFECT OF PCGTAW ON THE INCONEL 690 ALLOY WITH RESPECT TO MICROSEGREGATION ATTAINMENT IN COMPARISON WITH THE BASE METAL PROCESSED WITH AUTOGENOUS WELDING
}

\author{
VPLIV AVTOGENEGA VARJENJA S POSTOPKOM PCGTAW NA \\ ZLITINO INCONEL 690 GLEDE NA OBSEG MIKROSEGREGACIJ \\ V PRIMERJAVI S KONVENCIONALNIM AVTOGENIM \\ VARJENJEM S POSTOPKOM GTAW
}

\author{
Sengottaiyan Sivalingam ${ }^{1 *}$, Gurusamy Sureshkannan² \\ ${ }^{1}$ Department of Mechanical Engineering, KPR Institute of Engineering and Technology, Coimbatore, India \\ ${ }^{2}$ Department of Mechanical Engineering, Coimbatore Institute of Technology, Coimbatore, India \\ Prejem rokopisa - received: 2018-06-04; sprejem za objavo - accepted for publication: 2018-09-06
}

doi:10.17222/mit.2018.114

\begin{abstract}
The mechanical properties and microstructure of weldments are always an imperative concern of researchers; therefore, the change from continuous gas tungsten arc welding (GTAW) to pulsed-current gas tungsten arc welding (PCGTAW) was investigated for alloy 690, using the autogenous welding method. The mechanical properties like the tensile strength and impact were examined for both variants (continuous and pulsed-current gas tungsten arc welding). The microstructure was the susceptible parameter, revealing a complete formation of the weldments. Hence, a complete analysis with an optical microscope of up to $400 \mu \mathrm{m}$ and a SEM of up to $7000 \mu \mathrm{m}$ was performed during the described examination. This analysis showed that the formation of the secondary phase was negligible in the case of the pulsed-current method, which was superior to the gas tungsten arc welding, exhibiting a tensile strength of $641 \mathrm{MPa}$ and an impact strength of $66 \mathrm{~J}$.

Keywords: PCGTAW, GTAW, mechanical properties, SEM

Mehanskim lastnostim in mikrostrukturi zvarov raziskovalci vselej posvečajo še posebno pozornost. Zato so avtorji članka raziskovali prehod s kontinuirnega obločnega varjenja $\mathrm{z}$ volframovo elektrodo $\mathrm{v}$ zaščitnem plinu (GTAW) na pulzirajoče tokovno obločno varjenje $\mathrm{z}$ volframovo elektrodo pod zaščitnim plinom (PCGTAW) zlitine Inconel $690 \mathrm{z}$ uporabo autogene (brez dodajnega materiala) varilne metode. Določili in primerjali so mehanske lastnosti (natezno trdnost in udarno žilavost) obeh različic varjenja (kontinuirno in tokovno pulzno obločno varjenje z volframovo elektrodo pod zaščitnim plinom). Popolna tvorba mikrostrukture zvarov je bil odločujoč parameter oz. kriterij. Izvedli so kompletno metalografsko analizo pod optičnim mikroskopom do $400 \mu \mathrm{m}$ in z vrstičnim elektronskim mikroskopom (SEM) do $7000 \mu \mathrm{m}$. Te analize so pokazale, da je prišlo do zanemarljive tvorbe sekundarnih faz $\mathrm{v}$ primeru metode $\mathrm{s}$ pulzirajočim električnim tokom. Ta metoda (PCGTAW) je boljša od obločnega varjenja z volframovo elektrodo pod zaščitnim plinom (GTAW), ker sta bili doseženi precej višja natezna trdnost $(641 \mathrm{MPa})$ in udarna žilavost zvara $(66 \mathrm{~J})$.

Ključne besede: postopek PCGTAW, postopek GTAW, mehanske lastnosti, SEM
\end{abstract}

\section{INTRODUCTION}

As we know, stainless steel is the first metal to undergo corrosion. ${ }^{1}$ Researchers have been involved into developing novel materials, such as nickel-based alloys which are less prone to sensitization and corrosion. This better quality exhibited by these alloys allows them to be used in different areas like the chemical industry and the nuclear-power-plant industry, specifically for steam generators. $^{2-5}$ A varying high-temperature atmosphere always enhances the susceptibility to pitting corrosion, stress-cracking corrosion (SCC), trans-granular stresscorrosion cracking (TGSCC) and inter-granular stresscracking corrosion (IGSCC), like in the cases of steam generators and most of the thermal-power-plant sectors.

*Corresponding author e-mail

sivalaiyaa@gmail.com
To resolve this issue, the material used should exhibit a much better strength and good weldability. ${ }^{6-8}$ Most of the complex structures used today are welded to have permanent joints. The material exhibiting both characteristics (good strength and weldability) is nickel-based alloy 600. This alloy was first used in nickel alloys showing good strength in comparison with stainless steel with regard to the corrosion resistance. ${ }^{9,10}$ It is used in new areas like steam-generator tubing and other hightemperature corrosive environments. Alloy 600 is not completely resistant to different types of corrosion, depending on the environment, in which it is used, ${ }^{11}$ the structural property ${ }^{12}$ and the atmosphere, to which it is exposed. ${ }^{13}$ One of the reasons for this is its lower percentage of chromium, which is $15 \%$ of its weight.

This shows its need for further improvement, which can be carried out by increasing the chromium content. Therefore, super alloy 690 with a higher chromium 
content (about $30 \%$ of its weight) was introduced to overcome the corrosion with a higher resistance towards it, specifically in an oxidizing environment. So, super alloy Inconel-690 is usually applied as the melting-pot material. ${ }^{14}$ When Inconel-690 is continually exposed to a high-level radioactive material, a depletion of $\mathrm{Cr}$ from the alloy takes place, causing inter-granular attacks and other difficulties, which lead to the alloy's degradation. ${ }^{15}$ To overcome this problem, it is essential to make an alternative material for the melting pot or use a chemical-diffusion-fence coating to prevent the degradation of the melting-pot material. ${ }^{16,17}$ Inconel 690 exhibits outstanding mechanical properties and is used for steam generators of nuclear power plants. Hot tubes, usually made from Inconel series 600 and 690 or Incoloy 800, are significant components of a nuclear reactor's steam generator. ${ }^{18,19}$ Lee et al. ${ }^{20}$ examined the deformation characteristic of Inconel 690 under loading using a variety of environmental conditions and high strain rates. For example, steam-generator hot tubes can be subjected to high stresses during an operation owing to the gravity and liquid flow. ${ }^{21,22}$ The wear due to the fretting of SG tubes finally received attention and we should be able to diminish the fretting wear and assure a long-term integrity. The researchers realized many examinations of the SG-tube fretting wear and life predictions with the help of the data from macroscopic analyses of the wear coefficient, wear volume and so on. ${ }^{23-27}$ In addition, a microscopic analysis of fretting wear involves cracks, structures, oxidation processes and the characteristics of the oxide debris between contact surfaces. ${ }^{28-31}$

This super alloy has been studied and analyzed for various mechanical and metallurgical properties. Some of the outcomes show that it is slightly harder to weld than the other metals; GTAW welds were made with fillers I-52 and I-82 and it was observed that I-52 was better with respect to the strength of alloy 690 . The detailed result of GTAW with fillers I-52 and I-82 was discussed. ${ }^{32}$ Reports on steam generators examined with a boiling-water-reactor (BWR) analysis say that a fait ure $^{33-34}$ like cracking often exists in the heat-affectedzone and fusion-zone weldments. This finding allows the researchers to search for novel materials. So, the effectiveness of alloy 690 was proved with GTAW. In addition, there should be an improvement in terms of the microsegregation of the alloys. This major issue is addressed by using PCGTAW of Inconel 690. Thus, the most suitable filler chosen by H. T. Lee et al. is I-52 while I-82 reveals the tensile strength of around 570 $\mathrm{MPa}$; they also report a better weldability of the I-52 filler. The I-52 filler weldments exhibit columnar dendrites whereas I-82 exhibits equiaxed dendrites. I-82 has a higher tensile strength than I-52. In I-82, the formation of voids and cross slips leads to a fracture, while I-52 is better in this respect. ${ }^{35}$ Filler-based weldments show various characteristics while welding without a filler is autogenous welding. The above results clearly justify the change from GTAW to PCGTAW. Instead of using fillers, an alternative welding method was used to improve the characteristics to the level of the base metal and thus, for the analysis, autogenous GTAW and PCGTAW are compared. The autogenous method was not carried out for Inconel 690, which brought a new aspect to this research. The features of the weldments obtained with mechanical and microstructural analyses are revealed in the sections below. Section 1 includes the introduction discussing the 690 alloys with respect to the previous critical reviews in terms of weldability and different suitable welding techniques. Section 2 emphasizes the experimental setting for the welding. Section 3 describes the results obtained and the crucial outcomes. Section 4 reveals the conclusions and explains how to undertake further studies.

\section{EXPERIMENTAL PART}

Inconel 690 was procured in the hot-rolled form with a thickness of $4 \mathrm{~mm}$ and a spectroscopic test was carried out on the plate to ensure that the chemical composition was in line with the standard reference. ${ }^{36}$ The composition given in weight \% was $\mathrm{Ni} 61.86, \mathrm{Cr} 28.38$, and the remaining amount covered $\mathrm{C}, \mathrm{Mn}, \mathrm{P}, \mathrm{S}, \mathrm{Si}, \mathrm{Cu}$ and $\mathrm{Fe}$. The weldments of autogenous GTAW and PCGTAW are shown in Figures 1a and 1b. The metal plate was sliced into dimensions of $(130 \times 55 \times 4) \mathrm{mm}$ with the help of a wire-cut EDM machine. Before the welding, the plate was cleaned with a 200-grade emery sheet and acetone in order to remove oil, grease and other contaminants. The weldments were fabricated with an ultra-arc inverter TIG 315 BP machine using the GTAW and PCGTAW autogenous processes. Since the autogenous process was used, the welding had to be done on both sides to obtain the full depth of penetration with four passes as seen on Figures 1c and 1d. Argon was used as the shielding gas to prevent the molten metal from contamination and to improve the arc stability with a flow rate of $15 \mathrm{~L} / \mathrm{min}$.

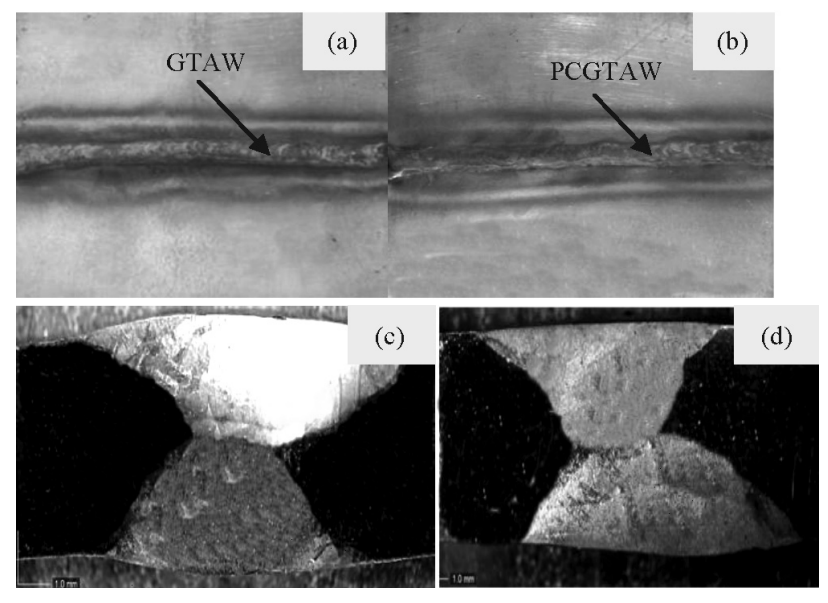

Figure 1: Photographic images of weldments made with: a) autogenous GTAW, b) autogenous PCGTAW, macrostructure images of the weld joints: c) autogenous GTAW, d) autogenous PCGTAW 


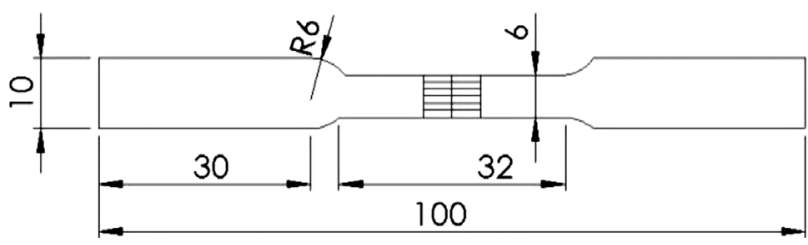

Figure 2: Schematic diagram showing the dimensions of a tensile specimen

The welding parameters employed in this study were a GTAW current of $125 \mathrm{~A}$, a voltage of $10 \mathrm{~V}$ and a heat input of $1.968 \mathrm{KJ} / \mathrm{mm}$. For PCGTAW, they included a current of $10 \mathrm{~A}$, a voltage of $125 \mathrm{~V}$, a pulse frequency of $7 \mathrm{~Hz}$, a pulse width of $34 \mathrm{~mm}$ and a heat input of 0.878 $\mathrm{KJ} / \mathrm{mm}$. The heat supplied during GTAW and PCGTAW was calculated using formulae 1 and 2 , and the corresponding input values were obtained.

The formula used to calculate the heat input for GTAW is given below:

$$
H=\frac{I \times V}{S} \times \eta \text { in }\left(\mathrm{kJ} \mathrm{mm}^{-1}\right)
$$

The following formulae were used to calculate the heat input for PCGTAW:

$$
\begin{aligned}
I_{\mathrm{m}} & =\frac{\left(I_{\mathrm{p}} \times t_{\mathrm{p}}\right)+\left(I_{\mathrm{b}} \times t_{\mathrm{b}}\right)}{\left(t_{\mathrm{p}}+t_{\mathrm{b}}\right)} \text { in }(\mathrm{A}) \\
H & =\frac{I_{\mathrm{m}} \times V}{S} \times \eta \text { in }\left(\mathrm{kJ} \mathrm{mm}^{-1}\right)
\end{aligned}
$$

where, $I_{\mathrm{m}}$ is the mean current in $\mathrm{A} ; I_{\mathrm{p}}$ is the pulse current in $\mathrm{A} ; I_{\mathrm{b}}$ is the background current in $\mathrm{A} ; t_{\mathrm{b}}$ is the background current duration in $\mathrm{ms} ; t_{\mathrm{p}}$ is the pulsecurrent duration in $\mathrm{ms} ; S$ is the welding speed in $\mathrm{mm} / \mathrm{min} ; V$ is the voltage in $\mathrm{V} ; \eta$ is the arc efficiency for GTAW and PCGTAW, taken as $70 \% .{ }^{37}$

In order to carry out a metallographic characterization, the welded plates were sliced into different pieces along their transverse direction. A weld coupon is a combination of the base metal, heat-affected zone and fusion zone. Silicon carbide (SiC) grit paper ranging from 200 to 2000 grade was used to polish the weldments manually. Then the samples were polished with alumina powder $(0.5 \mu \mathrm{m})$ and water to obtain the mirror finish with the help of a double-disc polishing machine. This was followed by electrolytic etching $(10 \mathrm{w} / \%$ oxalic acid, $12 \mathrm{~V}$ for $52 \mathrm{~s}$ ) performed on the weld samples to reveal the final microstructures. Optical and scanning electron microscopy were used to observe the microstructures of the etched samples. Energy dispersive $\mathrm{X}$-ray spectroscopy (EDS) was used to analyze and quantify the alloying-element segregation in the weldments. The sliced weld coupons were mechanically characterized with tensile, impact and bend tests in ambient conditions. As per the ASTM E8/E-8M-13a standard, the weld coupons were cut into three samples to perform the tensile test. The strength and ductility of the weld joints were measured with a universal testing machine (Instron 8801). Three test trials were made to ensure the repeatability. The toughness of the weld samples were measured with the Charpy V-notch impact test, in three trials. This test was carried out as per the ASTM E-23 standard. In order to understand a weld joint's ability to withstand the bending load, a root bend test was performed as per the ASTM E190 standard.

\section{RESULTS AND DISCUSSION}

\subsection{Macrostructure examination}

Macroscopic images of the alloy-690 weldments made with autogenous PCGTAW and GTAW are shown in Figures 1c and 1d. The weldments also underwent an NDT. The macroscopic examination as well as the NDT reveal the absence of abnormalities like porosities, cracks and defects. This test shows that the optimized welding parameters were adopted, and fusion was found to be good with the fluid flow, showing an enhancement in the weldments in achieving a better quality. During the macrostructure examination of GTAW and PCGTAW, no defects like cracks or abnormalities were found, as seen on the photographs in Figures 1a and 1b, respectively. This shows that the optimized welding parameters were adopted, and fusion was found to be good with the fluid flow, all together enhancing the weldments, which exhibited a better quality.

\subsection{Microstructure examination}

The microstructures of the weldments produced with conventional and pulsed-current GTAW are shown in Figure 3. Figures $\mathbf{3 a}$ and $\mathbf{3 b}$ show the microstructures of
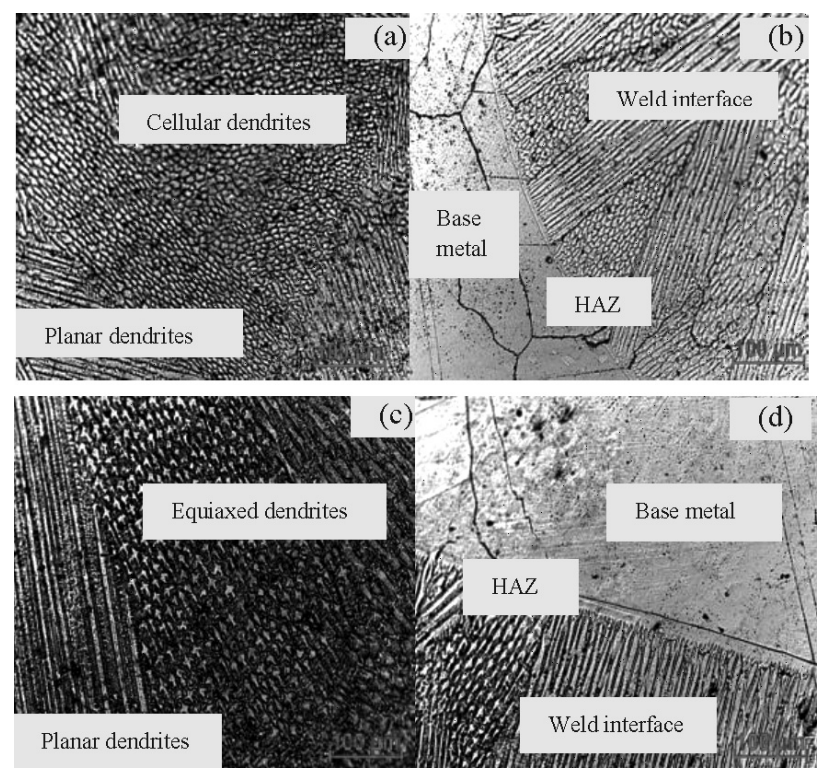

Figure 3: Optical-microscope pictures of the weld joints of autogenous GTAW: a) fusion zone, b) weld interface. Optical-microscope pictures of the weld joints of autogenous PCGTAW: c) fusion zone, d) weld interface 
different zones of the conventional GTAW weldments, namely, the fusion zone and the weld interface, respectively. The fusion zone consists of the following parts: (i) planar dendrites, (ii) cellular dendrites. Some of the coarse grains are seen in the HAZ in Figure 3b. This examination clearly shows that the planar dendrites are noticed at the fusion boundary and in the center, the cellular dendrites are seen.

Microstructures of the pulsed-current weldments are shown in Figures 3c and 3d. The microstructure of the fusion zone consists of (i) planar dendrites and (ii) equiaxed dendrites as shown in Figure 3c. The weld interface along with the fusion zone, HAZ and base metal are shown in Figure 3d. This analysis showed that planar dendrites are identified at the fusion boundary, whereas equiaxed dendrites are noticed in the area close to the weld.

This examination of the GTAW weldments clearly depicts that planar dendrites are noticed at the fusion boundary, while the area close to the weld reveals cellular dendrites, as shown in Figures 3a and 3b. The analysis of the PCGTAW weldments indicates that planar dendrites are identified at the fusion boundary, whereas the area close to the weld shows equiaxed dendrites, as seen in Figures $\mathbf{3 c}$ and $\mathbf{3 d}$.

\subsection{Tensile testing}

The tensile test of the GTAW- and PCGTAW-processed metal was done on a universal testing machine (UTM). The weld samples were tested several times to get the mean values, which are listed in Table 1. From these values, it is clear that the PCGTAW sample has more strength than the GTAW sample. The photographs of the tested samples are shown in Figures $\mathbf{4 a}$ and $\mathbf{4 b}$. SEM fractographs reveal the presence of microvoids, causing a failure, which occurred in the ductile mode as shown in Figures $\mathbf{4 c}$ and $\mathbf{4 d}$.

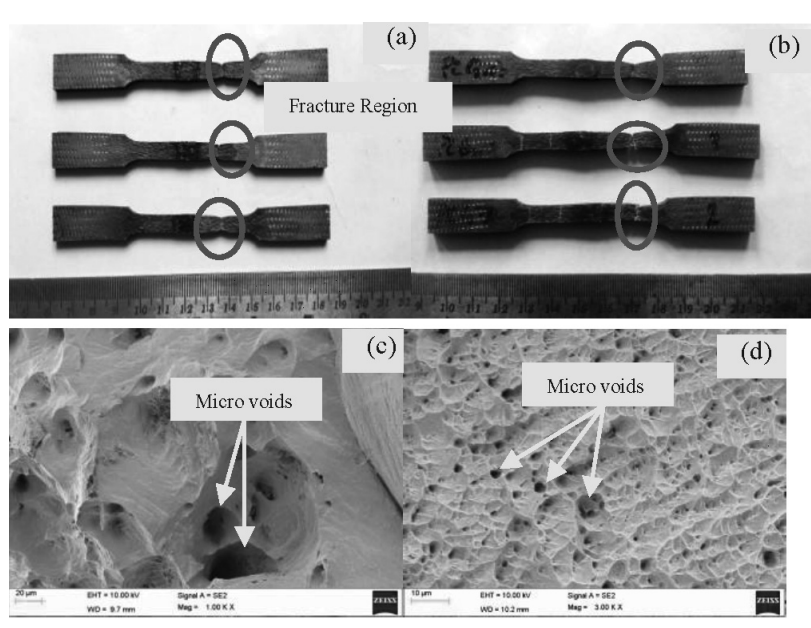

Figure 4: Photographs of the tensile test of fractured specimens: a) autogenous GTAW, b) autogenous PCGTAW. Photographs of SEM fractographs of tensile fractured specimens: c) autogenous GTAW, d) autogenous PCGTAW
The strength values of the welded samples are listed in Table 1. This shows that the strength of PCGTAW $(641 \mathrm{MPa})$ is $20 \%$ greater than that of GTAW (511 $\mathrm{MPa})$; hence, PCGTAW is stronger when compared to GTAW. The strength of PCGTAW is more or less equal to the base metal. The elemental values shown in Table 2 indicate a severe segregation of $\mathrm{Cr}$ in the interdendritic region of GTAW, which is higher than that of PCGTAW, revealing that PCGTAW is superior with regard to the joint strength.

Table 1: Results of the tensile tests of the welds produced using autogenous GTAW and PCGTAW

\begin{tabular}{|c|c|c|c|}
\hline Welding process & Trial no. & \multicolumn{1}{|c|}{$\begin{array}{c}\text { UTS } \\
(\mathrm{MPa})\end{array}$} & $\begin{array}{c}\text { Average } \\
\text { UTS (MPa) }\end{array}$ \\
\hline Alloy 690 & \multicolumn{3}{|c|}{637.9} \\
\hline \multirow{2}{*}{ Autogenous GTAW } & 1 & 488.4 & \multirow{2}{*}{511} \\
\cline { 2 - 3 } & 2 & 506.6 & \multirow{2}{*}{641} \\
\cline { 2 - 3 } & 3 & 539.6 & \\
\hline \multirow{3}{*}{ Autogenous PCGTAW } & 1 & 639 & \multirow{2}{*}{641} \\
\cline { 2 - 3 } & 2 & 641 & \\
\cline { 2 - 3 } & 3 & 643 & \\
\hline
\end{tabular}

\subsection{Impact testing}

The impact test of the GTAW and PCGTAW metal was done using the Charpy method. This test was done to measure the objects' ability to resist a high rate of loading. It was done for multiple trails and the average amount of the energy absorbed by a specimen and the toughness values were measured. This test indicates that the pulsed-current weld sample had a higher ability to absorb the energy than the GTAW sample. The photographs of the tested samples are shown in Figure 5. SEM fractographs reveal the presence of microvoids, causing a failure, which occurred in the ductile mode as shown in Figure 5.

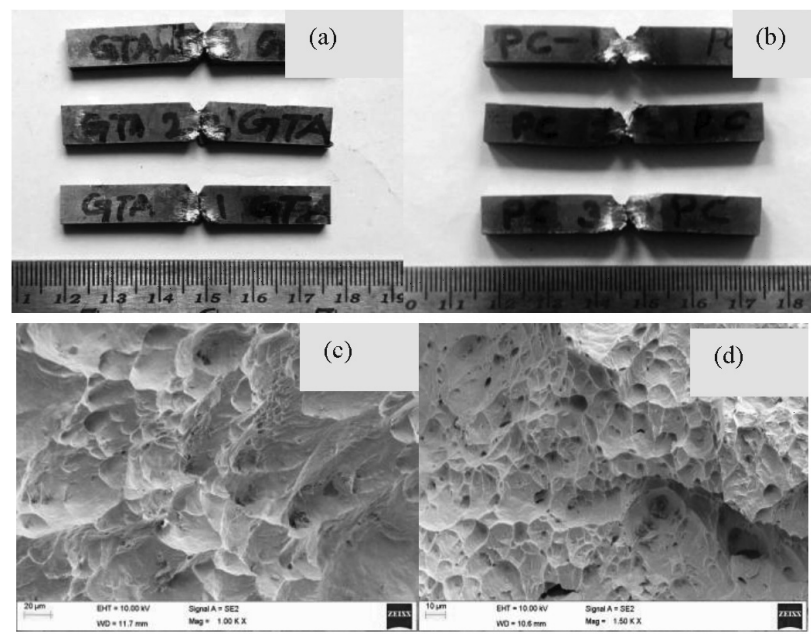

Figure 5: Impact test of the fractured specimens: a) autogenous GTAW, b) autogenous PCGTAW; photographs of SEM fractographs of impact-fractured specimens: c) autogenous GTAW, d) autogenous PCGTAW 
The impact toughness value for the base metal is $71.3 \mathrm{~J}$; autogenous GTAW shows the average value of 42.6 $\mathrm{J}$ and autogenous PCGTAW shows the average value of $66 \mathrm{~J}$. This indicates that the toughness of PCGTAW is $54.92 \%$ greater than that of GTAW, hence exhibiting a better tendency to absorb energy. This was proven with the SEM/EDS examinations of the secondary phases obtained with PCGTAW.

\subsection{SEM/EDS studies}

\section{Autogenous GTAW}

SEM/EDS results acquired from different GTAW zones (the weld center and weld interface) are shown in Figures $6 \mathbf{a}$ and $\mathbf{6 b}$. The values of the major alloying elements such as $\mathrm{Ni}, \mathrm{Cr}$, Fe obtained with the EDS analysis are shown in Table 2. A high-magnification SEM micrograph of the fusion-zone weld center is shown in Figure 6a. It is obvious that planar dendrites are enriched all over the weld centre. It is also noticed that secondary TCP (topologically closed packed) phases are in the fusion-zone weld center. Figure 6a (i, ii) shows the EDS analysis of the weld-center (WC) dendrite core and interdendritic region, respectively. From Figure 6a (i, ii), it is clear that the interdendritic region is enriched with $\mathrm{Cr}$. The dendrite core alloying-element chemical composition matches the base-metal compo- sition. Figure $\mathbf{6 b}$ shows a high-magnification SEM image of the weld interface. It also contains planar dendrites throughout the weldments. The weld-interface EDS analysis of the dendrite core and interdendritic region is shown in Figure $\mathbf{6 b}$ (iii, iv). An observation similar to that of the weld center is noticed.

\section{Autogenous PCGTAW}

SEM/EDS results obtained from different PCGTAW zones (the weld center, WC, and weld interface, WI) are shown in Figures $\mathbf{6 c}$ and $\mathbf{6 d}$. It is found that planar and equiaxed dendrites are enriched all over the weld center. Figure 6c (i, ii) shows the EDS analysis of the weldcenter dendrite core and interdendritic region indicating that the chemical composition of the alloying elements matches the composition of the base metal. Figure 6 shows a high-magnification image of the weld interface. It also contains planar dendrites throughout the weldments. The weld-interface EDS analysis of the dendrite core and interdendritic region is shown in Figure 6d (iii, iv). An observation similar to that of the weld center is noticed.

The change from GTAW to PCGTAW is advantageous due to the reasons discussed henceforth. The outcomes of GTAW and PCGTAW are shown in Figures $\mathbf{6 a}$ and $\mathbf{6 b}$ ) and (i-iv), and Figures $\mathbf{6 c}$ and $\mathbf{6 d}$ ) and (i-iv), respectively. The temperature-gradient parameter slowly

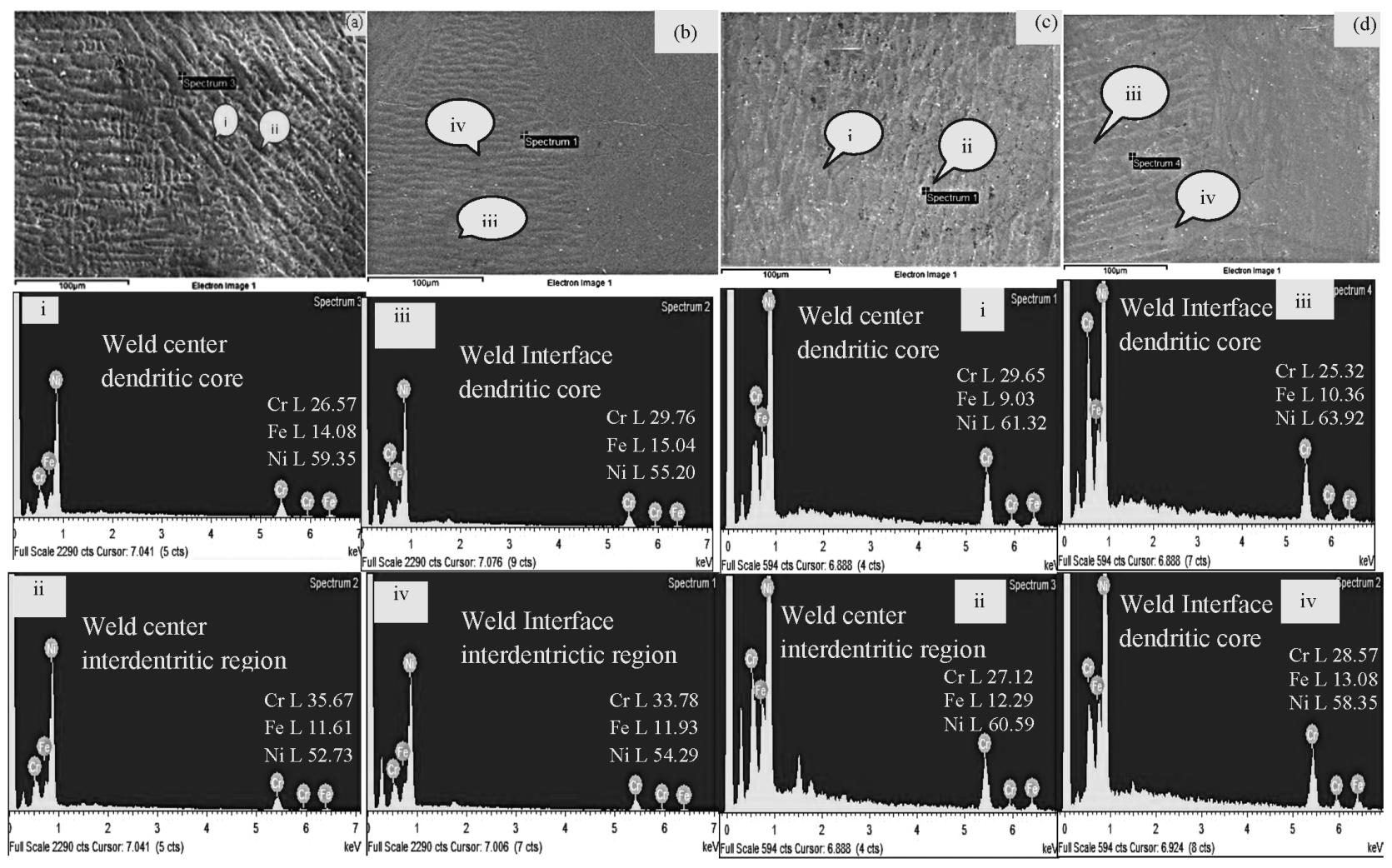

Figure 6: SEM/EDS analysis for autogenous GTAW: a) SEM weld center, b) SEM weld interface, i) EDS of weld-center dendritic core, ii) EDS of weld-center interdendritic region, iii) EDS of weld-interface dendritic core, and iv) EDS of weld-interface interdendritic region. SEM/EDS analysis for autogenous PCGTAW: c) SEM weld center, d) SEM weld interface, i) EDS of weld-center dendritic core, ii) EDS of weld-center interdendritic region, iii) EDS of weld-interface dendritic core, and iv) EDS of weld-interface interdendritic region 
decreases from the cores of the weldments to the fusion zones. This temperature distribution allows the formation of equiaxed dendrites in the weldments, shown only in the case of PCGTAW. The fluid flow is found to be exceptional owing to the cyclic repetition of solidification and melting due to the intermittent supply of heat. Superior solidification provides for a better fusion zone with a narrow HAZ. These supporting parameters are attained in the PCGTAW weldments, having the values of Ni-61.32, Cr-29.65 and Fe-9.03 while the base-metal values are Ni-61.86, $\mathrm{Cr}-28.38$ and $\mathrm{Fe}-10.40$. The $\mathrm{SEM} / \mathrm{EDS}$ reports depicted the amount of microsegregation in the dendritic and interdendritic regions of GTAW and PCGTAW. The welding process caused microsegregation affecting the mechanical and metallurgical properties of the weldments. The amounts of microsegregation in different areas can be found using the Scheil equation. This equation was used to study the amount of microsegregation in the Ni-Cr-Fe alloys of Inconel 690.

$$
k=\frac{C_{\text {core }}}{C_{0}}
$$

Here, $C_{\text {core }}$ - the elemental level in the dendrite core, $C_{0}$ - the elemental level in the base metal

The value of $\mathrm{k}$ represents the elemental level in a particular area. If the value of $k$ is less than $1(k<1)$ in the dendrite core area, it indicates microsegregation; but if the value of $\mathrm{k}$ is greater than $1(k>1)$, the segregation is in the interdendritic core area. In the study, the SEM/EDS analyses were carried out to find the elemental level in the dendritic and interdendritic core zones of the weldments, taking into account $\mathrm{Ni}, \mathrm{Cr}$ and Fe. Table 2 shows the values of $\mathrm{k}$ in the dendritic core area of weld samples. This clearly shows that the microsegregation in the PCGTAW samples $(k=1.044)$ is lower than in the GTAW weld samples $(k=0.93)$. It is observed that the value of $\mathrm{Cr}$ is less than 1 , which indicates Cr segregation in the interdendritic zone of the GTAW weldment, whereas in PCGTAW there is no microsegregation. This study also indicates that the heat input is a major factor for the microsegregation of alloying elements; in addition, the solidification time increases with an increase in the microsegregation of the alloying elements in the interdendritic zone of weld samples. The heat input during GTAW $(1.96 \mathrm{KJ} / \mathrm{mm})$ has a slow cooling rate, whereas during PCGTAW $(0.878 \mathrm{KJ} / \mathrm{mm})$, it has a high cooling rate. This increases the solidification and diffusion of the alloying elements and allows more time for cooling, which increases the segregation of $\mathrm{Cr}$ in the interdendritic regions of the GTAW samples.

Table 2: Elemental levels in the dendritic core zone of the weld center (k)

\begin{tabular}{|c|c|c|c|}
\hline METHODS & $\mathrm{Ni}$ & $\mathrm{Cr}$ & $\mathrm{Fe}$ \\
\hline GTAW & 1.01 & 0.93 & 1.51 \\
\hline PCGTAW & 0.99 & 1.044 & 0.969 \\
\hline
\end{tabular}

If the heat input is lower, the time required for the formation of secondary phases is also lower. Therefore, during PCGTAW the secondary phases are completely reduced. The EDS analysis clearly shows that the secondary phases' interdendritic regions match the $\sigma$ phases. These $\sigma$ phases are the main source for hot cracking in the fusion zones of weld samples. Finally, it is noted that the formation of secondary phases in the pulsed-current welding mode is completely reduced.

\section{CONCLUSIONS}

Nickel alloy 690 was welded with autogenous GTAW and PCGTAW. Both methods were compared and the following observations were made. The overall test report shows that PCGTAW is better than GTAW due to the following reasons,

- There are no defects in the weldments obtained with GTAW and PCGTAW elucidating the superior quality of a particular type of welding.

- In both cases, the fusion zone shows planar dendrites, but they are smaller in the case of PCGTAW. Further, the equiaxed dendrites are found only in the PCGTAW samples, confirming a superior quality of these welds, which exhibit better strength.

- The tensile test clearly shows that the strength of the PCGTAW weldments is almost equal to the base metal, being $641 \mathrm{MPa}$.

- The toughness value of $66 \mathrm{~J}$ confirms the superiority of autogenous PCGTAW.

- The SEM/EDS examination clearly shows that the microsegregation is lower in the case of PCGTAW.

\section{REFERENCES}

${ }^{1}$ T.-Y. Kuo, H.-T. Lee, Effects of filler metal composition on joining properties of alloy 690 weldments, Mater. Sci. Eng. A, 338 (2002), 202-212, doi:10.1016/S0921-5093(02)00063-1

${ }^{2} \mathrm{P}$. Kritzer, Corrosion in high-temperature and supercritical water and aqueous solutions: a review, J. Supercrit. Fluids, 29 (2004), 1-29, doi:10.1016/S0896-8446(03)00031-7

${ }^{3}$ S. Teysseyre, G. S. Was, Stress corrosion cracking of austenitic alloys in supercritical water, Corrosion, 62 (2006), 1100-1116, doi:10.5006/1.3278244

${ }^{4}$ R. S. Dutta, R. Tewari, P. K. De, Effects of heat-treatment on the extent of chromium depletion and caustic corrosion resistance of Alloy 690, Corros. Sci., 49 (2007), 303-318, doi:10.1016/j.corsci. 2006.05.043

${ }^{5}$ Y. Y. Chen, L. B. Chou, H. C. Shih, Factors affecting the electrochemical behavior and stress corrosion cracking of Alloy 690 in chloride environments, Mater. Chem. Phys., 97 (2006), 37-49, doi:10.1016/j.matchemphys.2005.07.053

${ }^{6}$ G. Sui, J. M. Titchmarsh, G. B. Heys, J. Congleton, Stress corrosion cracking of alloy 600 and alloy 690 in hydrogen/steam at $380{ }^{\circ} \mathrm{C}$, Corros. Sci., 39 (1997) 3, 565-587, doi:10.1016/S0010938X(97)86103-3

${ }^{7}$ J. B. Ferguson, H. F. Lopez, Oxidation products of INCONEL alloys 600 and 690 in pressurized water reactor environments and their role in intergranular stress corrosion cracking, Metall. and Mat. Trans. A, 37 (2006) 8, 2471, doi:10.1007/BF02586220 


\section{S. SIVALINGAM, G. SURESHKANNAN: EFFECT OF PCGTAW ON ALLOY 690 WITH RESPECT TO MICROSEGREGATION ...}

${ }^{8}$ M. Casales, V. M. Salinas-Bravo, A. Martinez-Villafañe, J. G. Gonzalez-Rodriguez, Effect of heat treatment on the stress corrosion cracking of alloy 690, Mater. Sci. Eng. A, 332 (2002), 223-230, doi:10.1016/S0921-5093(01)01747-6

${ }^{9}$ G. S. Was, P. Ampornrat, G. Gupta, S. Teysseyre, E. A. West, T. R. Allen, K. Sridharan, L. Tan, Y. Chen, X. Ren, C. Pister, Corrosion and stress corrosion cracking in supercritical water, J. Nucl. Mater., 371 (2007), 176-201, doi:10.1016/j.corsci. 2015.10.017

${ }^{10}$ B. T. Lu, J. L. Luo, Y. C. Lu, A mechanistic study on lead-induced passivity-degradation of nickel-based alloy, J. Electrochem. Soc., 154 (2007), C379-C389, 0013-4651/2007/154(8)/C379/11/

${ }^{11}$ M.-K. Ahn, H.-S. Kwon, J.-H. Lee, Predicting susceptibility of alloy 600 to intergranular stress corrosion cracking using a modified electrochemical potentiokinetic reactivation test, Corrosion, 51 (1995) 6, 441-449, doi:10.5006/1.3293610

${ }^{12}$ W. T. Tsai, M. J. Sheu, J. T. Lee, The stress corrosion crack growth rate in sensitized alloy 600 in thiosulfate solution, Corros. Sci., 38 (1996), 33-45, doi:10.1016/0010-938X(96)00097-2

${ }^{13}$ W.-T. Tsai, C.-S. Chang, J.-T. Lee, Effects of shot peening on corrosion and stress corrosion cracking behaviors of sensitized alloy 600 in thiosulfate solution, Corrosion, 50 (1994) 2, 98-105, doi:10.5006/1.3293507

${ }^{14}$ D. Zhu, C. W. Kim, D. E. Day, Corrosion behavior of Inconel 690 and 693 in an iron phosphate melt, J. Nucl. Mater., 336 (2005), 47-53, doi:10.1016/j.jnucmat.2004.08.010

${ }^{15}$ P. Sengupta, N. Soudamini, C. P. Kaushik, R. K. Mishra, G. B. Kale, K. Raj et al., Corrosion of alloy 690 process pot by sulfate containing high level radioactive waste at feed stage, J. Nucl. Mater., 374 (2008), 185-191, doi: 10.1016/j.jnucmat.2007.08.005

${ }^{16}$ P. Sengupta, D. Rogalla, H. W. Becker, G. K. Dey, S. Chakraborty, Development of graded Ni-YSZ composite coating on alloy 690 by pulsed laser deposition technique to reduce hazardous metallic nuclear waste inventory, J. Hazard. Mater., 192 (2011), 208-221, doi:10.1016/j.jhazmat.2011.05.006

${ }^{17}$ T. Narita, Diffusion barrier coating system concept for high temperature applications, Can. Metall. Q, 50 (2011), 278-290, doi:10.1179/1879139511Y.0000000014

${ }^{18}$ H. Y. Zhang, Y. H. Lu, M. Ma, J. Li, Effect of precipitated carbides on the fretting wear behavior of Inconel 600 alloy, Wear, 315 (2014), 58-67, doi:10.1016/j.wear.2014.03.012

${ }^{19} \mathrm{P}$. Berge, J. R. Donati, Materials requirements for pressurized water reactor steam generator tubing, Nucl. Technol., 55 (1981) 88-104, doi:10.13182/NT81-A32833

${ }^{20}$ W. S. Lee, C. Y. Liu, T. N. Sun, Deformation behavior of Inconel 690 super alloy evaluated by impact test, Mater. Process. Technol., 153-154 (2004), 219-225, doi:10.1016/j.jmatprotec.2004.04.275

${ }^{21}$ P. L. Ko, R. J. Rogers, Analytical and experimental studies of tube/support interaction in multi-span heat exchanger tubes, Nucl. Eng. Des., 65 (1981) 399-409, doi:10.1016/0029-5493(81)90102-3

${ }^{22}$ M. Hassan, J. Riznic, Evaluation of the integrity of steam generator tubes subjected to flow induced vibrations, J. Press. Vess. T. Asme, 136 (2014), 1-11, doi:10.1115/PVP2013-97751
${ }^{23}$ J. Li, Y. H. Lu, H. Y. Zhang, L. Xin, Effect of grain size and hardness on fretting wear behavior of Inconel 600 alloys, Tribol. Int., 81 (2015), 215-222, doi:10.1016/j.triboint.2014.08.005

${ }^{24}$ H. Y. Zhang, Y. H. Lu, M. Ma, J. Li, Effect of precipitated carbides on the fretting wear behavior of Inconel 600 alloy, Wear, 315 (2014), 58-67, doi:10.1016/j.wear.2014.03.012

${ }^{25}$ J. Li, Y. H. Lu, Effects of displacement amplitude on fretting wear behaviors and mechanism of Inconel 600 alloy, Wear, 304 (2013), 223-230, doi:10.1016/j.wear.2013.04.027

${ }^{26}$ Z. H. Wang, Y. H. Lu, J. Li, T. Shoji, Effect of $\mathrm{pH}$ value on the fretting wear behavior of Inconel 690 alloy, Tribol. Int., 95 (2016), 162-169, doi:10.1016/j.triboint.2015.10.025

${ }^{27}$ J. Li, M. Ma, Y. H. Lu, L. Xin, Evolution of wear damage in Inconel 600 alloy due to fretting against Type 304 stainless steel, Wear, 346 (2015), 15-21, doi:10.1016/j.wear.2015.10.011

${ }^{28}$ L. Xin, Z. H. Wang, J. Li, Y. H. Lu, T. Shoji, Microstructural characterization of subsurface caused by fretting wear of Inconel 690TT alloy, Mater. Charact., 115 (2016), 32-38, doi:10.1016/j.matchar. 2016.03.010

${ }^{29}$ Y. Lee, I. Kim, The effect of subsurface deformation on the wear behavior of steam generator tube materials, Wear, 253 (2002), 438-447, doi:10.1016/S0043-1648(02)00157-6

${ }^{30}$ Y. Lee, H. Kim, H. Kim, C. Park, I. Kim, A comparative study on the fretting wear of steam generator tubes in Korean power plants, Wear, 255 (2003), 1198-1208, doi:10.1016/S0043-1648(03)00147-9

${ }^{31}$ N. Diomidis, S. Mischler, Third body effects on friction and wear during fretting of steel contacts, Tribol. Int., 44 (2011), 1452-1460, doi:10.1016/j.triboint.2011.02.013

${ }^{32}$ A. J. Sedriks, J. W. Schultz, M. A. Cordovi, Inconel alloy 690-A new corrosion resistant material, Inco Research \& Development Center Report, Boshoku Gijutsu, 28 (1979), 82-95

${ }^{33}$ V. N. Shah, P. E. MacDonald, Jet pump hold-down beam failure, Information Notice 93-101, US Nuclear Regulatory Commission, Aging and life extension of major light water reactor components, Amsterdam, Elsevier, 1993

${ }^{34}$ Cracking in the lower region of the core shroud in boiling water reactors, Information Notice 94-42, US Nuclear Regulatory Commission, 1994

${ }^{35}$ H. T. Lee, T. Y. Kuo, Analysis of microstructure and mechanical properties in alloy 690 weldments using filler metals I-82 and I-52, Sci. Technol. of Weld. Joining, 4 (1999) 2, doi:10.1179/ 136217199101537626

${ }^{36}$ Special metal data sheet, Alloy 690, http://www.Specialmetalswiggin.co.uk/pdfs/products/INCONEL\%20alloy\%20690.pdf, 03. 03.2018

${ }^{37}$ Long Xin, Zi Hao Wang, Jie Li, Yonghao Lu, Tetsuo Shoji, Microstructural characterization of subsurface caused by fretting wear of Inconel 690TT alloy, Mater. Charact., 115 (2016), 32-38, doi:10.1016/j.matchar.2016.03.010 